\title{
Impact of technostress on academic productivity of university students
}

\author{
Pallavi Upadhyaya ${ }^{1}$ (D) Vrinda $^{2}$
}

Received: 25 May 2020 / Accepted: 31 August 2020 / Published online: 11 September 2020

(C) The Author(s) 2020

\begin{abstract}
There has been increasing interest among researchers to understand the negative effects of technology, in the last two decades. Technostress or stress induced due to technology is extensively reported in the literature, among working professionals. Even though there has been an increased proliferation of digital devices in academia, there is a dearth of studies examining the prevalence of technostress and its impact among students. This study examines the prevalence of technostress among the younger population, in the age group of 18-28 years. Using a sample of 673 Indian private university students, this study cross-validated the technostress instrument. Increased use of technology in higher education has compelled students to complete all their academic work, including assessments, using technology. Technology-enhanced learning applications such as learning management systems, MOOCs and digital exam devices require students to develop ICT skills. The study also investigates the impact of technostress on the academic productivity of students. Findings reveal that the technostress instrument is valid to be used in the academic context, with minor modifications, and students experienced moderate levels of technostress. It was also found that technostress had a negative impact on the academic productivity of students.
\end{abstract}

Keywords Technostress $\cdot$ Academic productivity $\cdot$ Higher education $\cdot$ Students

\section{Introduction}

Developments in ICT and its ubiquity has accelerated the use of ICT among higher education institutions (HEIs). Technology is being extensively used for

Pallavi Upadhyaya

pallavi.upd@manipal.edu; https://orcid.org/0000-0003-4523-2051

Vrinda

vrinda.doc@manipal.edu; https://orcid.org/0000-0002-1542-299X

1 Manipal Academy of Higher Education, Manipal Institute of Management, Manipal 576104, India

2 Department of Commerce, Manipal Academy of Higher Education, Manipal, India 
automating academic processes and enhance the teaching and learning process. The use of Technology Enhanced Learning (TEL) has risen exponentially in academia, due to government incentives and to meet students' anticipations (Dunn \& Kennedy, 2019). Technology is being used for academic administration and student self-service, through applications such as student's life cycle management (Wang et al., 2018), learning management systems, MOOCs, integrated digital-based assessment (Barana et al., 2016) and attendance management system (Ofelia et al., 2017). Online learning and MOOCs were found to reduce the higher education costs for students (Deming et al., 2015) and students were found to have a positive perception towards integrating ICT in the classroom (Vahedi et al., 2019). For HEIs, ICT is found to aid in reducing distance barriers (Agarwal \& Mittal, 2018) and reduce paperwork (Pattinson, 2017). Besides, ICT enables HEIs to streamline academic administration, bring transparency, and speed up the academic data processing. Integrating technology in the classroom is believed to improve the teaching and learning process (Mirzajani et al., 2016).

While the benefits of technology cannot be argued, there has been increased interest in understanding the negative impact of technology on end-users. Technostress or "inability to cope with new technologies", have been extensively studied in the literature on the organization employees and its impact on job outcomes (Tarafdar et al., 2007, 2011b, Tarafdar et al., 2019; Torre et al., 2019). A recent review has reported the negative influence of technostress on employee's six psychological and behavioral outcomes, one of them being employee productivity (Sarabadani et al., 2018). Studies in technostress have focused on various groups like employees (Tarafdar et al., 2007, 2011a, b; Hauk et al., 2019) knowledge workers (Chen, 2015) and employees in their early retirement/older adults (Nimrod, 2017). A case study by Davies (2015) found that first-year psychology undergraduate students experienced test anxiety, computer anxiety, and technostress, during their first Online MCQ Assessment. On the contrary, Qi (2019), found that the use of mobile devices for academic purposes had no impact on technostress.

There is a dearth of empirical studies that have examined the prevalence of technostress among the younger generation, in particular, students. Technostress among students may lead to a higher burden on the higher education institutions through a decrease in productivity, dropouts, and deviation from academic work. Therefore, there is a need to examine the prevalence of technostress among students and its consequences. Students of the present generation have a different set of characteristics and habits, which makes them an interesting group to be studied. By 2020, new generation cohort steps into the business world and are called as Digital Natives (Rothman, 2016). These students are born in the Internet-connected world and ICT is part of their routine (Desai \& Lele, 2017). Digital Natives are habituated to immediate and autonomous access to information, multitasking, nonlinear learning, and dynamic graphics (Brooks \& Davis, 2018). Therefore, it would be interesting to test whether the technostress is relevant to this generation, its prevalence among various demographics of students, and its impact on academic productivity.

In this backdrop, we use the technostress scale proposed by Tarafdar et al. (2007) and validate the instrument in an academic context and measure the technostress levels among the undergraduate and postgraduate students, in a private university. The 
relationship between technostress and academic productivity is also examined. The research aims to address the following research questions:

- What is the validity of the technostress instrument on the student population?

- Is there any difference in technostress in students, based on gender, age, level of education, and experience with ICT?

- To what extent does the technostress impact the academic productivity of students?

\section{Literature review}

Drawing primarily from the transactional model, stress has been defined as "an individual psychological response to a situation, where the situation demands exceed the individual and situational capacity/resources or ability to cope with the situation" (Folkman \& Lazarus, 1980; Lazarus \& Folkman, 1984). Using sociotechnical and role theory, Tarafdar et al. (2007) explained that these stressors are the conditions (creators) that originate from social or role (role stressor) and technical or task (task stressor) or the use of ICTs (technology stressor).

Past research studies posit ICT as one of the causes of stress. The term 'Technostress' was first introduced by Brod (1984) and defined as "a modern disease of adaptation caused by an inability to cope with the new computer world technologies in an unhealthy manner". Clark and Kalin (1996) described that "technostress is not a disease, and is a negative psychological, behavioral and physiological impact caused, either directly or indirectly, by technology". Technostress creators are conceptualized as "job demands which require high physical, social, and cognitive skills, with an associated psychological cost” (Mahapatra \& Pati, 2018).

Technostress is referred by different terminologies such as technophobia and computer anxiety (Hung et al., 2011; Laspinas, 2015). Tarafdar et al. (2007) defined technostress as a "problem of adaptation that individual experiences, when he or she is unable to cope with new technology." and proposed a multi-dimensional scale with five components techno-overload, techno-invasion, techno-complexity, techno-insecurity, and techno-uncertainty.

\section{Technostress: A double-edged sword}

Researchers and practitioners have proposed technostress as 'a double-edged sword' (Qi, 2019), by considering both the positive and negative impact of technostress for individuals and their organizations. Tarafdar et al. (2019) proposed a revised framework of Technostress as a trifecta by considering techno-eustress, techno-distress, and information systems design. The framework incorporates both positive and negative outcomes of technostress, along with mitigating negative effects through appropriate IS design. The framework defines techno-eustress as the process in which an individual elucidate IS as challenging or thrilling, and the individual experiences good stress and results in positive outcomes. Techno-distress is defined as the process where an individual evaluates IS as a threat, experience "bad" stress, and encounters unfavorable outcomes. 
Schlachter et al. (2018) demonstrated that the use of ICT enables the task to be more portable and remotely accessible, leading to an increase in employees' performance, improved job satisfaction, and work-family balance. Ayyagari et al. (2011) found continuous connectivity with ICT enhances the work speed and thereby increases the productivity and quality of an individual life.

On the contrary, Wang et al. (2008) found that the employees from centralized and innovative organizations, often showcase peak level of technostress. The dark side of technology usage referred to as 'technostress' (Tarafdar et al., 2011a, b) has been extensively researched in the past, examining its impact on organizational behavior and psychological stress (Tarafdar et al., 2019). Technostress has been found to impact negatively on organizational behavior such as employee productivity (Hung et al., 2015), performance (Tarafdar et al., 2014), end-user satisfaction (Fuglseth \& Sorebo, 2014), job satisfaction (Kumar et al., 2013) and continuance commitment (RaghuNathan et al., 2008). Few studies also manifested the impact of technostress on psychological behavioral outcomes of an employee such as strain (Raghu-Nathan et al., 2008) or the extent to which the individual feels tired (Ayyagari et al., 2011). Researchers have reported several other behavioral outcomes of technostress such as burnout (Mahapatra \& Pati, 2018) and also physical health implications such as repetitive eyestrain, headaches, blood pressure, backaches, stomach problems, irritability and heart attacks (Tams et al., 2013). In an academic context, Samaha and Hawi (2016) found that there is a significant impact of mobile technology addiction on students' academic performance and satisfaction with life.

\subsection{Technology and digital natives}

The present generation students are often referred to as 'digital natives'. They possess technological fluency that is inherent ability to familiarize themselves with new technology demands, with greater ease (Prensky, 2001). Further, Prensky (2007) also quoted "students (digital natives) are insisting for these [new] technologies to be used as part of their education, in part because they are things that the students have already mastered and use in their daily lives, and in part, because they understand just how useful they can be". It is believed that current generation learners have well developed productive learning habits, multitasking, teamwork, but on the other side, digital natives are incapable of deep learning and productive work. Digital natives are believed to have sufficient ICT skills and adapt to changes (Joo et al., 2016).

Studies on these digital natives have reported positive effects of ICTs on academic performance. Qi (2019) found the use of mobile devices had a positive impact on students' academic performance. Morris and Morris (2010) found that technology-driven assessment in classroom boosts the academic performance among students. Insua et al. (2016) argued that, students are using ICT for their personal use, entertainment, and leisure time rather than academic use and found that higher use of ICT leads to better academic performance. Rabiu (2016) posited that the frequency of mobile phone usage does not considerably influence academic performance among undergraduate students. On the contrary, a study conducted by Jena (2015) among Indian University students found that, TEL results in burnout, reduced engagement in learning, poor academic performance, and intention to drop out. 
Tarafdar et al. (2019) in the trifecta model noted the significance of studying the demographical data due to the individual difference in handling the technology with confidence. Hence, we examine the association of students' demographic factors and level of technostress.

\subsection{Technostress and gender}

Several studies (Broos, 2005; Qi, 2019), has noted male students have a lower level of technostress as compared to females and they are involved with innovation performance using technology (Chandra et al., 2019). For female adolescents' frequency of internet and technology use is both psychologically and socially a complex affaire (Broos \& Roe, 2006) and experience more computer anxiety than male adolescents (Tekinarslan, 2008). There are also contradictory results observed that male employees experienced more technostress than female counterparts (Ragu-Nathan et al., 2008; Tarafdar et al., 2014). Based on the literature, we propose that

\section{H1: There is a difference in technostress levels of male and female students}

\subsection{Technostress and age}

A recent longitudinal study by Hauk et al. (2019) propose that age is positively associated with the level of technostress using cognitive theories on aging, where an individual experience deterioration of his/her motor skill over the age (Reuter et al., 2012). A meta-analysis by Hauk et al. (2018) posited that older adults find higher difficulties in using technology compared to younger adults, specifically with techno-overload and techno-complexity, which require a complex amount of cognitive abilities and physical condition. However, Ragu-Nathan et al. (2008) found that the technostress decreases as age increases. Most of the research studies are on the working population and their associated age ranges, with only a few studies focusing on students (Shu et al., 2011; Wang et al., 2008). Therefore, previous findings on age effects are contradictory. In the present study, we propose to examine the following hypothesis for the students grouped into two age groups (18-22 and 23-28 years)

H2: There is a difference in technostress levels of students with different age groups

\subsection{Technostress and level of education}

The literature on technostress in education is relatively limited. Rather, Ragu-Nathan et al. (2008) and Wang et al. (2008) found that the level of education inversely influences technostress. With the experience in computer learning, formally educated students experience less technostress (Tarafdar et al., 2011b). However, one study reported that education level has no significant relationship with technostress (Shu et al., 2011). With this mixed result, current research proposes below hypothesis: 
H3: There is a difference in technostress levels of undergraduate and postgraduate students.

\subsection{Technostress and level of ICT experience}

The ICT experience is referred to as "number of years of experience, with the use of technology". Zhao et al. (2020) confirmed a positive association of ICT experience with productivity and inverse association with technostress. Qi, (2019) found that there is no significant association of technostress with the level of ICT experience. Ragu-Nathan et al. (2008) found that managers with higher confidence in their ability to use ICTs experience less technostress. Higher levels of technostress are associated with less experience using technology (Shu et al., 2011). Therefore, we propose the following

H4: There is a difference in technostress levels of students with respect to their level of ICT experience.

\subsection{Technostress and productivity}

In Information systems discipline, productivity is often referred to as 'task productivity' and defined as 'the extent that an application improves the user's output per unit of time" (Torkzadeh \& Doll, 1999). Hysenbegasi et al. (2005) measured academic productivity using students' grade point average(GPA).

Tarafdar et al. (2007) conceptualized productivity as "increased work efficiency and output during work hours through mobile technologies as perceived by staff members". Tarafdar et al. (2007) found a negative impact of five technostress creators on productivity at the workplace. Lee et al. (2016) validated the inverse association of technostress from mobile communication on quality of life and employee productivity. Hung et al. (2011) found that 'ubiquitous technostress' or stress caused by the overuse of mobile phones at the workplace has a negative effect on employees' productivity. Based on the previous literature, the research model is presented in Fig. 1 and we propose that

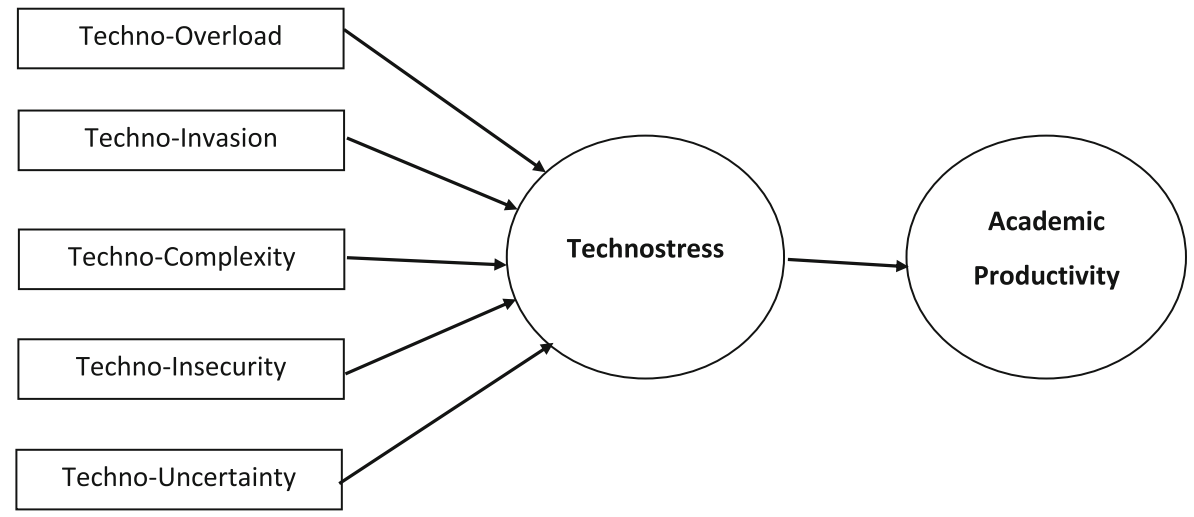

Fig. 1 Research model 
H5: Technostress has a negative effect on students' academic productivity.

\section{Research method}

The study was conducted in a multidisciplinary, private university in Southern India. The university uses ICT to automate the administration of academic data through the Student Lifecycle Management system. The university also conducts assessments through the digital exam pad systems. Technostress among students was measured using a 23 item scale proposed by Tarafdar et al. (2007). All the items were measured in five-point likert scale. Technostress was modeled as a second-order construct, with five sub-dimensions namely techno-overload, techno-invasion, techno-complexity, techno-insecurity, and techno-uncertainty. Techno-overload is defined as the effect of technology that forces students to work faster and longer. Techno-invasion is defined as the effect of technology that forces students to work beyond regular college hours and invades their personal lives. Techno-complexity is defined as a situation where technology makes students feel that their skill sets are inadequate. In the context of higher education, Techno-insecurity is defined as the situation where the students feel threatened about poor academic performance compared to other students, who have a better knowledge of using technology. Techno-uncertainty refers to a situation where frequent changes and upgrades in technology, create uncertainty for students. The sub-constructs techno-complexity, techno-insecurity and techno-uncertainty were modified and adapted to suit academic context.

Academic productivity was measured as a four-item scale adapted from previous works of Torkzadeh and Doll (1999) and Tarafdar et al. (2007). However, in this study, the scale was modified to the academic context. The changes done to the original instrument is elaborated in a separate section in the Appendix 2.

The research questionnaire was mailed to 2300 undergraduate and postgraduate students. Six hundred seventy two completed responses were received, after one follow up, with a response rate of $29 \%$. The respondents in the sample belonged to the age group of 18-28 years, with $80 \%$ of the students falling in the 18-22 age group. The median age of the sample is 20 . Among the respondents, $55 \%$ of students were male and $45 \%$ were female. Fifty-three percent of the students were undergraduates and the remaining were postgraduates. The students reported an average of 10 years of experience in using ICT.

\section{Analysis, results, and discussion}

\subsection{Technostress scale validation and reliability}

The initial review of data revealed the absence of any missing data in the responses received. A confirmatory factor analysis was run to ascertain the structure of the sub-constructs of technostress and ensure construct validity. The factor analysis with the principal component method and varimax rotation was used (Ho, 2006). The results indicated an acceptable value of Keiser-Meyer-Olkin Measure of Sampling Adequacy (KMO-SA) of 0.886. As per Malhotra (1999), values of KMO-MSA greater than 0.5 
would indicate the validity of the factor analysis. The output of the factor loadings of all the 23 items in the instrument in the rotated component matrix was observed and items with factor loadings of less than 0.5 were removed from further analysis. The factor loadings of all the items in the rotated component matrix are shown in Table 1.

It was observed that one item in Techno-overload (TO5) and three items, namely TIS1, TIS2, TIS3 of Techno-insecurity had a factor loading of less than 0.5 , therefore it was dropped from further analysis. As the scale is primarily developed considering working professionals, words such as workload in TO5 would be interpreted differently by the student group. When we observe items in Techno-insecurity, TIS1, TIS2, TIS3 all are related to threat due to new skills required and TIS4 and TIS5 are more focused

Table 1 Results of confirmatory factor analysis

\begin{tabular}{|c|c|c|c|c|c|c|}
\hline & $\begin{array}{l}\text { Techno } \\
\text { overload }\end{array}$ & $\begin{array}{l}\text { Techno } \\
\text { insecurity }\end{array}$ & $\begin{array}{l}\text { Techno } \\
\text { complexity }\end{array}$ & $\begin{array}{l}\text { Techno } \\
\text { insecurity }\end{array}$ & $\begin{array}{l}\text { Techno } \\
\text { uncertainty }\end{array}$ & $\begin{array}{l}\text { Academic } \\
\text { productivity }\end{array}$ \\
\hline TO1 & .786 & & & & & \\
\hline TO2 & .818 & & & & & \\
\hline TO3 & .723 & & & & & \\
\hline TO4 & .547 & & & & & \\
\hline TO5 & .489 & & & & & \\
\hline TI1 & & .695 & & & & \\
\hline TI2 & & .716 & & & & \\
\hline TI3 & & .741 & & & & \\
\hline TI4 & & .759 & & & & \\
\hline $\mathrm{TC} 1$ & & & .675 & & & \\
\hline TC2 & & & .795 & & & \\
\hline TC3 & & & .691 & & & \\
\hline TC4 & & & .710 & & & \\
\hline TC5 & & & .806 & & & \\
\hline TIS1 ${ }^{\mathrm{a}}$ & & & & .159 & & \\
\hline TIS2 ${ }^{\mathrm{a}}$ & & & & -.040 & & \\
\hline TIS3a & & & & .352 & & \\
\hline TIS4 & & & & .761 & & \\
\hline TIS5 & & & & .817 & & \\
\hline TU1 & & & & & .673 & \\
\hline TU2 & & & & & .783 & \\
\hline TU3 & & & & & .817 & \\
\hline TU4 & & & & & .804 & \\
\hline P1 & & & & & & .835 \\
\hline P2 & & & & & & .851 \\
\hline P3 & & & & & & .834 \\
\hline P4 & & & & & & .834 \\
\hline
\end{tabular}

a Items dropped 
on peer pressure. Inter item correlation was also observed higher among TIS4 and TIS5. Therefore, only two items of the construct were retained for analysis.

The reliability of the technostress constructs was ascertained, before further analysis. Table 2 presents the reliability statistics and the key descriptive statistics of the technostress dimensions and academic productivity. The Cronbach alpha of all the measures was found to be more than 0.7 , indicating an acceptable level of reliability and inter-item consistency of the scale (Nunnally, 1967).

Overall technostress level was found to be 3.15(on a scale of 5), which indicates a moderate level of technostress among students. Students had a positive perception of the role of technology in improving academic productivity, with a mean of 3.93. It is observed that overall students experience a moderate level of techno-overload (mean: 3.42), techno-uncertainty (mean:3.41), and techno-invasion (mean 3.31). Lower levels of techno-complexity (mean: 2.91) and techno-insecurity (mean: 2.68) is observed.

\subsection{Level of technostress among various student groups}

Technostress levels were compared between the different demographic profile of students. A series of independent sample t-tests were conducted to examine whether there exist significant levels of technostress among students grouped based on gender, age, level of education, and level of ICT experience. The results are presented in Table 3.

A comparison of technostress among male and female students revealed that female students experienced higher technostress than male students ( $\mathrm{t}: 2.872, p<0.01)$. Therefore, $\mathrm{H} 1$ was supported. Though the finding was in contradiction to earlier findings of employees in USA (Raghu-Nathan et al., 2008; Tarafdar et al., 2014) and China (Chen, 2015), it is consistent with technostress studies of students (Broos, 2005; Qi, 2019; Tekinarslan, 2008). Further, out of the five technostress components, female students experienced higher technostress in techno-complexity (t: 5.719, $p<0.001)$ and techno-uncertainty $(\mathrm{t}: 3.241, \mathrm{p}<0.001)$.

The students were grouped into two age groups (18-22 and 23-28 years) and the differences in the levels of technostress observed. The t-tests results revealed that students in the age group of 23-28 years experienced higher technostress than the younger students of the age group 18-22 years ( $\mathrm{t}: 2.281, p<0.05)$. Older student groups

Table 2 Measurement items reliability statistics

\begin{tabular}{lllll}
\hline Construct & Number of items & Cronbach alpha & Mean & Standard deviation \\
\hline Techno-overload $^{\mathrm{a}}$ & 4 & 0.787 & 3.43 & 0.78 \\
Techno-invasion & 4 & 0.781 & 3.31 & 0.87 \\
Techno-complexity & 5 & 0.843 & 2.91 & 0.83 \\
Techno-insecurity & 2 & 0.701 & 2.68 & 0.93 \\
Techno-uncertainty & 4 & 0.790 & 3.42 & 0.64 \\
Academic productivity $^{\mathrm{a}}$ & 4 & 0.877 & 3.93 & 0.7 \\
Technostress $^{\mathrm{a}}$ & 19 & & 3.15 & 0.53 \\
\hline
\end{tabular}

a Values after dropping items 
Table 3 Comparison of technostress levels among various student groups

\begin{tabular}{|c|c|c|c|c|}
\hline & $\begin{array}{l}\text { Frequency } \\
\text { (percentage) } N=672\end{array}$ & $\begin{array}{l}\text { Technostress level } \\
\text { mean (standard deviation) }\end{array}$ & t-value & $\begin{array}{l}\text { Significance } \\
\text { level }\end{array}$ \\
\hline Age & & & 2.481 & $0.013^{*}$ \\
\hline $18-22$ & $535(80)$ & $3.13(0.53)$ & & \\
\hline $23-28$ & $137(20)$ & $3.25(0.54)$ & & \\
\hline Gender & & & 2.872 & $0.004^{* *}$ \\
\hline Male & $373(55)$ & $3.09(0.53)$ & & \\
\hline Female & $299(45)$ & $3.21(0.53)$ & & \\
\hline Level of education & & & 3.427 & $0.001 * * *$ \\
\hline Undergraduate & $359(53)$ & $3.08(0.52)$ & & \\
\hline Postgraduate & $313(47)$ & $3.22(0.54)$ & & \\
\hline Years of experience of using ICT & & & 2.160 & $0.031 *$ \\
\hline $0-10$ years & $414(62)$ & $3.2(0.53)$ & & \\
\hline More than 10 years & $258(38)$ & $3.1(0.53)$ & & \\
\hline
\end{tabular}

$* \mathrm{p}<0.05$

$* * p<0.01$

$* * * \mathrm{p}<0.001$

experienced significantly higher levels techno-invasion (t:4.219, $p<0.001)$ and techno-overload (t:3.051, $p<0.01)$. The results supported $\mathrm{H} 2$ and were consistent with a recent study by Hauk et al. (2018). The analysis of students' level of education and technostress levels also showed significantly higher technostress among postgraduate students $(\mathrm{t}: 3.427, \mathrm{p}<0.001)$ and stress was in particular, higher in techno-complexity $(\mathrm{t}: 3.7, \mathrm{p}<0.001)$ and techno overload (t: 3.6, $\mathrm{p}<0.001)$. The results indicated support for $\mathrm{H} 3$. Though there are no studies comparing technostress of undergraduates and postgraduates, the reason for higher technostress could be due to higher levels of academic workload for older students and postgraduates. Technostress induced by techno-overload is a common feature observed in postgraduates and older students.

The average number of years of experience with ICT in the sample was found to be 10 years. Therefore, students were grouped into two groups: those with ICT experience of 10 or less and those with more than 10 years of experience. The comparison of their technostress showed that students with lesser ICT experience experienced higher technostress levels $(\mathrm{t}: 2.16, p<0.05)$, and particularly higher in techno-complexity (t:4.498, $p<0.001)$, techno-insecurity (t:2.9, $p<0.01)$. The result was consistent with previous studies (Ragu-Nathan et al., 2008). Therefore, H4 was supported.

\subsection{Technostress and academic productivity}

To assess the impact of technostress on academic productivity, the structural model was assessed using AMOS 21. CFI (Comparative Fit Index) and TLI (Tucker Lewis Index) are popular goodness of fit measure in SEM and values closer to 1 indicates a good model. A cut-off value of 0.9 for CFI and TLI is considered to be an acceptable model 
(Hair et al., 1998; Hu \& Bentler, 1999). Lower values of badness-of-fit measures of Root Mean squared error of approximation (RMSEA) and Standardised Root Mean Square Residual (SRMR), closer to zero, indicates a good model (Kline, 2005). Hu and Bentler (1999) recommend a cut off value of 0.08 for SRMR and 0.06 for RMSEA. The standardized estimates and model fit indices are presented in Table 4.

The model fit indices for SEM, suggested by Hu and Bentler (1999), namely, CFI (0.920), TLI(0.910), SRMR(0.0728) and RMSEA(0.057) were found to be within acceptable cutoff criteria. The results also indicated a negative impact of technostress on academic productivity $(p<0.01)$, therefore H5 was supported. The results were consistent with past studies on technostress on different groups of users (Tarafdar et al., 2007; Hung et al., 2011; Ayyagari et al., 2011; Tarafdar et al., 2011b; Lee et al., 2016).

Overall, among the five technostress dimensions, technostress induced by techno-uncertainty was found to be least. Techno-invasion was found to be the highest contributor of technostress among students. This could be due to the increasing ubiquity of technology, which has led to the invasion of personal time. Surprisingly, in contrast to previous literature (Hauk et al., 2018), technostress induced by techno-complexity is also experienced by this younger group of students. Our findings indicate that among students, the high-risk group that perceives technology as complex is older postgraduate level students, female students, and students with lesser ICT experience.

Table 4 : Results of structural equation model

\begin{tabular}{ll}
\hline & Standardised estimates \\
\hline Academic productivity $\leftarrow$ technostress & $-0.136^{* * *}$ \\
Techno-overload $\leftarrow$ technostress & $0.669^{* * *}$ \\
Techno-invasion $\leftarrow$ technostress & $0.711^{* * *}$ \\
Techno-complexity $\leftarrow$ technostress & $0.706^{* * *}$ \\
Techno-insecurity $\leftarrow$ technostress & $0.632^{* * *}$ \\
Techno-uncertainty $\leftarrow$ technostress & $0.284^{* * *}$ \\
P1 $\leftarrow$ academic productivity & $0.785^{* * *}$ \\
P2 $\leftarrow$ academic productivity & $0.832^{* * *}$ \\
P3 $\leftarrow$ academic productivity & $0.806^{* * *}$ \\
P4 $\leftarrow$ academic productivity & $0.781^{* * *}$ \\
Model fit indices & \\
Chi-square (df) & $706(224)$ \\
Chi-square/df & 3.152 \\
CFI & 0.920 \\
TLI & 0.910 \\
SRMR & .0728 \\
RMSEA & .057 \\
\hline
\end{tabular}

\footnotetext{
$* * p<0.01$
}

$* * * p<0.001$ 


\section{Theoretical and managerial implications}

The study makes an important theoretical contribution of cross-validating the technostress instrument of Tarafdar et al. (2007) among the students. The results indicate that the instrument is suitable to measure the prevalence of technostress among students, with minor modifications. However, there is a need to improve the Techno-insecurity scale for better reliability and accuracy, in the academic context.

The findings of the paper have several managerial implications for higher education institutions(HEIs). As the results indicate a higher impact of techno-invasion and techno-overload, HEIs must plan and schedule academic work in a manner that provides adequate time to complete the academic work and have a balanced lifestyle. HEIs can mitigate the impact of Techno-complexity by choosing user-friendly, familiar educational technology, and providing adequate training for the students.

It was observed that female students experienced higher levels of techno-complexity. The results are consistent with the results of technostress studies conducted on student population (Broos, 2005; Qi, 2019) and reiterate the need to identify at-risk students to help them cope with the technostress. As it was observed that older students, postgraduates, and students with lesser ICT experience had higher levels of technostress, HEIs must identify and train students, with lesser ICT experiences, during their admission to the program. HEIs need to conduct technology orientation sessions to increase the familiarization of technology, that would be used in their academic work. Also, special training sessions for those with lesser ICT experience would help mitigate technostress.

Results indicated that there is a negative impact of technostress on academic productivity. The results were consistent with the previous studies conducted in organizational contexts (Tarafdar et al., 2011a; Chen, 2015). HEIs may administer the technostress instrument among students to identify the high-risk students and counsel them to reduce technostress, thereby improving their academic performance. Students experiencing higher levels of technostress may be assigned a student mentor from the peer group, to improve the confidence of the student in the use of technology.

The results have implications for future employers as well. Results indicate the presence of technostress among the younger population, despite considerable higher ICT experience and popular belief that the younger generation is techno-savvy and have lesser technostress. It is necessary for employers that they do not take this group for granted and provide adequate ICT training for newly recruited employees to reduce burnout. As there are a variety of ICT applications, there is constant pressure to upgrade technical skills. Students also need adequate time to transition from academic to work life.

\section{Limitations, scope of future research and conclusions}

The study has a few limitations. The demographic characteristics of gender, age, experience with ICT, level of education were only considered for examining the technostress among students. However, past research shows that personality traits moderate the perceptions of technostress creators that impact the job outcome (Srivastava et al., 2015) and proactive personality traits reduce the negative effects of technostress (Hung et al., 2015). Future studies may include the personality traits of the students and test their impact on the technostress. Second, the study focused on technostress creators and did not include 
technostress inhibitors such as technical support provision, literacy facilitation, and involvement facilitation (Ragu-Nathan et al., 2008). Further research may investigate the association of techno inhibitor in solving the issues related to techno complexity and techno invasion. The techno-insecurity scale can be refined further to improve its reliability. It is therefore recommended to identify the sources of techno-insecurity among students.

Funding Open access funding provided by Manipal Academy of Higher Education, Manipal.

\section{Appendix 1. Research Instrument}

Age

Gender: Male/Female

Years of experience using ICT:

Education Level: Undergraduate/Postgraduate

\section{Techno-overload}

TO1. I am forced by this technology to work much faster.

TO2. I am forced by this technology to do more work than I can handle.

TO3. I am forced by this technology to work with very tight time schedules.

TO4. I am forced to change my work habits to adapt to new technologies.

TO5. I have a higher workload because of increased technology complexity. *dropped.

\section{Techno-invasion}

TI1. I spend less time with my family due to this technology.

TI2. I have to be in touch with my work even during my vacation due to this technology.

TI3. I have to sacrifice my vacation and weekend time to keep current on new technologies.

TI4. I feel my personal life is being invaded by this technology.

\section{Techno-complexity}

TC1. I do not know enough about this technology to handle my work satisfactorily.

TC2. I need a long time to understand and use new technologies.

TC3. I do not find enough time to study and upgrade my technology skills.

TC4. I find my peers know more about computer technology than I do.

TC5. I often find it too complex for me to understand and use new technologies.

\section{Techno-insecurity}

TIS1. I feel a constant threat to my performance due to new technologies. *dropped.

TIS2. I have to constantly update my skills to avoid poor performance. * dropped.

TIS3. I am threatened by classmates with newer technology skills. *dropped.

TIS4. I do not share my knowledge with my classmates for fear of poor performance.

TIS5. I feel there is less sharing of knowledge among classmates for fear of poor performance. 


\section{Techno-uncertainty}

TU1. There are always new developments in the technologies we use in our institute.

TU2. There are constant changes in computer software in our institute.

TU3. There are constant changes in computer hardware in our institute.

TU4. There are frequent upgrades in computer networks in our institute.

\section{Academic Productivity}

$\mathrm{P} 1$. This technology helps to improve the quality of my academic work.

$\mathrm{P} 2$. This technology helps to improve my academic productivity.

P3. This technology helps me to accomplish more academic work than would otherwise be possible.

P4. This technology helps me to perform my academic work better.

\section{Appendix 2: Summary of Modifications Done to the Original Instrument}

Table 5 Summary of modifications done to the instrument

\begin{tabular}{|c|c|c|c|}
\hline Construct & Original item & Adapted item & Comments \\
\hline $\begin{array}{l}\text { Techno-complexity } \\
\quad \text { (TC1) }\end{array}$ & $\begin{array}{l}\text { I do not know enough } \\
\text { about this technology to } \\
\text { handle my job } \\
\text { satisfactorily }\end{array}$ & $\begin{array}{l}\text { I do not know enough } \\
\text { about this technology to } \\
\text { handle my work } \\
\text { satisfactorily }\end{array}$ & $\begin{array}{l}\text { "Job" was replaced with } \\
\text { work }\end{array}$ \\
\hline $\begin{array}{l}\text { Techno-complexity } \\
\text { (TC4) }\end{array}$ & $\begin{array}{l}\text { I find new recruits to this } \\
\text { organization know more } \\
\text { about computer } \\
\text { technology than I do }\end{array}$ & $\begin{array}{l}\text { I find my peers know more } \\
\text { about computer } \\
\text { technology than I do }\end{array}$ & $\begin{array}{l}\text { "New recruits to this } \\
\text { organisation" replaced } \\
\text { with "my peers" }\end{array}$ \\
\hline $\begin{array}{l}\text { Techno-insecurity } \\
\text { (TIS1) }\end{array}$ & $\begin{array}{l}\text { I feel constant threat to my } \\
\text { job security due to new } \\
\text { technologies }\end{array}$ & $\begin{array}{l}\text { I feel a constant threat to } \\
\text { my performance due to } \\
\text { new technologies }\end{array}$ & $\begin{array}{l}\text { "Job security" replaced } \\
\text { with "performance".In } \\
\text { academic context poor } \\
\text { academic performance } \\
\text { or lower grades is a } \\
\text { concern of students }\end{array}$ \\
\hline $\begin{array}{l}\text { Techno-insecurity } \\
\text { (TIS2) }\end{array}$ & $\begin{array}{l}\text { I have to constantly update } \\
\text { my skills to avoid being } \\
\text { replaced }\end{array}$ & $\begin{array}{l}\text { I have to constantly update } \\
\text { my skills to avoid poor } \\
\text { performance }\end{array}$ & $\begin{array}{l}\text { "Being replaced" } \\
\text { substituted with "poor } \\
\text { performance" }\end{array}$ \\
\hline $\begin{array}{l}\text { Techno-insecurity } \\
\text { (TIS3) }\end{array}$ & $\begin{array}{l}\text { I am threatened by } \\
\text { coworkers with newer } \\
\text { technology skills }\end{array}$ & $\begin{array}{l}\text { I am threatened by } \\
\text { classmates with newer } \\
\text { technology skills }\end{array}$ & $\begin{array}{l}\text { "Coworkers" replaced with } \\
\text { "classmates" }\end{array}$ \\
\hline $\begin{array}{l}\text { Techno-insecurity } \\
\text { (TIS4) }\end{array}$ & $\begin{array}{l}\text { I do not share my } \\
\text { knowledge with my } \\
\text { coworkers for fear of } \\
\text { being replaced }\end{array}$ & $\begin{array}{l}\text { I do not share my } \\
\text { knowledge with my } \\
\text { classmates for fear of } \\
\text { poor performance }\end{array}$ & Same as TIS2 and TIS3 \\
\hline $\begin{array}{l}\text { Techno-insecurity } \\
\text { (TIS5) }\end{array}$ & $\begin{array}{l}\text { I feel there is less sharing } \\
\text { of knowledge among } \\
\text { coworkers for fear of } \\
\text { being replaced }\end{array}$ & $\begin{array}{l}\text { I feel there is less sharing } \\
\text { of knowledge among } \\
\text { classmates for fear of } \\
\text { poor performance }\end{array}$ & Same as TIS2 and TIS3 \\
\hline
\end{tabular}


Table 5 (continued)

\begin{tabular}{llcc}
\hline Construct & Original item & Adapted item & Comments \\
\hline $\begin{array}{c}\text { Techno-uncertainty } \\
\text { (TU1-TU4) }\end{array}$ & $\begin{array}{c}\text { TU1:There are always new } \\
\text { developments in the } \\
\text { technologies we use in } \\
\text { our organisation }\end{array}$ & $\begin{array}{c}\text { TU1: There are always } \\
\text { new developments in } \\
\text { the technologies we use } \\
\text { in our institute }\end{array}$ & $\begin{array}{c}\text { In all items the word } \\
\text { "organization" replaced } \\
\text { with "institute" }\end{array}$ \\
$\begin{array}{c}\text { Academic } \\
\text { Productivity P1-P4 }\end{array}$ & $\begin{array}{c}\text { P1: This technology helps } \\
\text { to improve the quality } \\
\text { of my work }\end{array}$ & $\begin{array}{c}\text { This technology helps } \\
\text { to improve the quality } \\
\text { of my academic work }\end{array}$ & $\begin{array}{c}\text { In all items, prefix of } \\
\text { "academic" was added } \\
\text { to terms "productivity" } \\
\text { and "work" }\end{array}$ \\
\hline
\end{tabular}

Open Access This article is licensed under a Creative Commons Attribution 4.0 International License, which permits use, sharing, adaptation, distribution and reproduction in any medium or format, as long as you give appropriate credit to the original author(s) and the source, provide a link to the Creative Commons licence, and indicate if changes were made. The images or other third party material in this article are included in the article's Creative Commons licence, unless indicated otherwise in a credit line to the material. If material is not included in the article's Creative Commons licence and your intended use is not permitted by statutory regulation or exceeds the permitted use, you will need to obtain permission directly from the copyright holder. To view a copy of this licence, visit http://creativecommons.org/licenses/by/4.0/.

\section{References}

Agarwal, A. K., \& Mittal, G. K. (2018). The role of ICT in higher education for the 21 st century: ICT as a change agent for education. Multidisciplinary Higher Education, Research, Dynamics \& Concepts: Opportunities \& Challenges for Sustainable Development, 1(1), 76-83.

Ayyagari, R., Grover, V., \& Purvis, R. (2011). Technostress: Technological antecedents and implications. MIS Quarterly, 35(4), 831-858.

Barana, A., Bogino, A., Fioravera, M., \& Marchisio, M. (2016). Digital support for university guidance and improvement of study results. Procedia - Social and Behavioral Sciences, 228, 547-552. https://doi. org/10.1016/j.sbspro.2016.07.084.

Brod, C. (1984). Technostress: The human cost of the computer revolution. Reading: Addison Wesley Publishing Company.

Brooks, S., \& Davis, T. (2018). Engaging digital natives in an educational setting. In E. Langran \& J. Borup (Eds.), Proceedings of society for information technology \& teacher education international conference (pp. 3761-3764). Washington, DC: Association for the Advancement of Computing in Education (AACE) https://www.learntechlib.org/primary/p/209961/.

Broos, A. (2005). Gender and information and communication technologies (IT) anxiety: Male self assurance and female hesitation. Cyber Psychology \& Behaviour, 8(1), 21-31. https://doi.org/10.1089 /cpb.2005.8.21.

Broos, A., \& Roe, K. (2006). The digital divide in the play station generation: Self-efficacy, locus of control and ICT adoption among adolescents. Poetics, 34, 306-317. https://doi.org/10.1016/j.poetic.2006.05.002.

Chandra, S., Shirish, A., \& Srivastava, S. C. (2019). Does technostress inhibit employee innovation? Examining the linear and curvilinear influence of technostress creators. Communications of the Association for Information Systems, 44(1), 299-331. https://doi.org/10.17705/1CAIS.04419.

Chen, L. (2015). Validating the technostress instrument using a sample of Chinese knowledge workers. Journal of International Technology and Information Management, 24(1), 65-81 Retrieved from https://scholarworks.lib.csusb.edu/jitim/vol24/iss1/5.

Clark, K., \& Kalin, S. (1996). Technostressed out? How to cope in the digital age. Library Journal, 121(13), 30-32. 
Davies, G. (2015). Online MCQ assessment anxiety amongst first year undergraduate psychology students: A case study. Journal of Perspectives in Applied Academic Practice, 3(1), 84-89.

Deming, D. J., Goldin, C., Katz, L. F., \& Yachtman, N. (2015). Can online learning bend the higher education cost curve. American Economic Review, 100(5), 496-501. https://doi.org/10.1257/aer.p20151024.

Desai, S. P., \& Lele, V. (2017). Correlating internet, social networks and workplace - a case of generation Z students. Journal of Commerce \& Management Thought, 8(4), 802-815. https://doi.org/10.5958 /0976-478X.2017.00050.7.

Dunn, T. J., \& Kennedy, M. (2019). Technology enhanced learning in higher education; motivations, engagement and academic achievement. Computers \& Education, 137, 104-113. https://doi. org/10.1016/j.compedu.2019.04.004.

Folkman, S., \& Lazarus, R. S. (1980). An analysis of coping in a middle-aged community sample. Journal of Health and Social Behavior, 21(3), 219-239. https://doi.org/10.2307/2136617.

Fuglseth, A. M., \& Sørebø, Ø. (2014). The effects of technostress within the context of employee use of ICT. Computers in Human Behavior, 40, 161-170. https://doi.org/10.1016/j.chb.2014.07.040.

Hair, J. F., Anderson, R. E., Tatham, R. L., \& Black, W. C. (1998). Multivariate data analysis. Upper Saddle River: Prentice Hall.

Hauk, N., Hüffmeier, J., \& Krumm, S. (2018). Ready to be a silver surfer? A meta-analysis on the relationship between chronological age and technology acceptance. Computers in Human Behavior, 84, 304-319. https://doi.org/10.1016/j.chb.2018.01.020.

Hauk, N., Goritz, A. S., \& Krumm, S. (2019). The mediating role of coping behavior on the age-technostress relationship : A longitudinal multilevel mediation model. PLoS One, 14(3), e0213349. https://doi. org/10.1371/journal.pone.0213349.

Ho, R. (2006). Handbook of univariate and multivariate data analysis and interpretation with SPSS. Boca Raton: Chapman and Hall/CRC. https://doi.org/10.1201/9781420011111.

Hu, L. T., \& Bentler, P. M. (1999). Cutoff criteria for fit indexes in covariance structure analysis: Conventional criteria versus new alternatives. Structural Equation Modeling: A Multidisciplinary Journal, 6(1), 1-55.

Hung, W-H., Chang, L-M. \& Lin, C-H. (2011). Managing the risk of overusing mobile phones in the working environment: A study of ubiquitous technostress. In Seddon, P.B. \& Gregor S. (Eds.) PACIS 2011 proceedings, 81, Brisbane, Australia: Queensland University of Technology. Retrieved from http://aisel. aisnet.org/pacis2011/81

Hung, W., Chen, K., \& Lin, C. (2015). Telematics and informatics does the proactive personality mitigate the adverse effect of technostress on productivity in the mobile environment ? Telematics and Informatics, 32 (1), 143-157. https://doi.org/10.1016/j.tele.2014.06.002.

Hysenbegasi, A., Hass, S. L., \& Rowland, C. R. (2005). The impact of depression on the academic productivity of university students. The Journal of Mental Health Policy and Economics, 8(3), 145151 Retrieved from http://www.icmpe.org/test1/journal/issues/v8pdf/8-145_text.pdf.

Insúa, P., Bernaras, E., \& Bully, P. (2016). Computers in human behavior use of information and communications technology, academic performance and psychosocial distress in university students. Computers in Human Behavior, 56, 119-126. https://doi.org/10.1016/j.chb.2015.11.026.

Jena, R. K. (2015). Technostress in ICT enabled collaborative learning environment: An empirical study among Indian academician. Computers in Human Behavior, 51, 1116-1123. https://doi.org/10.1016/j. chb.2015.03.020.

Joo, Y. J., Lim, K. Y., \& Kim, N. H. (2016). Computers \& education the effects of secondary teachers' technostress on the intention to use technology in South Korea. Computers \& Education, 95, 114-122. https://doi.org/10.1016/j.compedu.2015.12.004.

Kline, R. B. (2005). Principles and practice of structural equation modeling (2nd ed.). New York: The Guilford Press.

Kumar, R., Lal, R., Bansal, Y., \& Sharma, S. K. (2013). Technostress in relation to job satisfaction and organisational commitment among IT professionals. International Journal of Scientific and Research Publications, 3(12), 12-14.

Laspinas, L. M. (2015). Technostress: Trends and challenges in the 21 st century knowledge management. European Scientific Journal, 11(2), 205-217 Retrieved from https://eujournal.org/index. php/esj/article/view/4970/4732.

Lazarus, R. S., \& Folkman, S. (1984). Stress, appraisal, and coping. New York: Springer.

Lee, S. B., Lee, S. C., \& Suh, Y. H. (2016). Technostress from mobile communication and its impact on quality of life and productivity. Total Quality Management \& Business Excellence, 27(7-8), 775-790. https://doi.org/10.1080/14783363.2016.1187998.

Mahapatra, M. \& Pati, S. P. (2018). Technostress creators and burnout a job demands-resources perspective. In Aubert, B., Compeau, D. \& Tarafdar, M. (Eds.) Proceedings of the 2018 ACM SIGMIS conference on 
computers and people research, (pp. 70-77). New York, USA: Association for Computing Machinery. doi.org/10.1145/3209626.3209711.

Malhotra, N. (1999). Marketing research: An applied orientation (3rd ed.). New Delhi: Prentice Hall India.

Mirzajani, H., Mahmud, R., Fauzi Mohd Ayub, A., \& Wong, S. L. (2016). Teachers' acceptance of ICT and its integration in the classroom. Quality Assurance in Education, 24(1), 26-40. https://doi.org/10.1108 /QAE-06-2014-0025.

Morris, N. P., \& Morris, N. P. (2010). Podcasts and Mobile assessment enhance student learning experience and academic performance. Bioscience Education, 16(1), 1-7. https://doi.org/10.3108/beej.16.1.

Nimrod, G. (2017). Technostress : Measuring a new threat to well- being in later life. Aging \& Mental Health, 22(8), 1086-1093. https://doi.org/10.1080/13607863.2017.1334037.

Nunnally, J. C. (1967). Psychometric theory. New York: McGraw-Hill.

Ofelia, M., Pedro, Z. S., \& Heffernan, N. T. (2017). An integrated look at middle school engagement and learning in digital environments as precursors to college attendance. Technology, Knowledge and Learning, 22(3), 243-270. https://doi.org/10.1007/s10758-017-9318-z.

Pattinson, C. (2017). ICT and green sustainability research and teaching. IFAC-PapersOnLine, 50(1), 1293812943. https://doi.org/10.1016/j.ifacol.2017.08.1794.

Prensky, M. (2001). Digital natives, digital immigrants. On the Horizon, 9(5), 1-6.

Prensky, M. (2007). How to teach with technology: Keeping both teachers and students comfortable in an era of exponential change. Emerging Technologies for Learning, 2(4), 40-46.

Qi, C. (2019). A double-edged sword ? Exploring the impact of students' academic usage of mobile devices on technostress and academic performance. Behaviour \& Information Technology, 38(12), 1337-1354. https://doi.org/10.1080/0144929X.2019.1585476.

Rabiu, H. (2016). Impact of mobile phone usage on academic performance among secondary school students in Taraba State, Nigeria. European Scientific Journal, 12(1), 1857-7881. https://doi.org/10.19044 /esj.2016.v12n1p466.

Ragu-Nathan, T. S., Tarafdar, M., Ragu-Nathan, B. S., \& Tu, Q. (2008). The consequences of technostress for end users in organizations: Conceptual development and validation. Information Systems Research, 19(4), 417-433. https://doi.org/10.1287/isre.1070.0165.

Reuter, E. M., Voelcker-Rehage, C., Vieluf, S., \& Godde, B. (2012). Touch perception throughout working life: Effects of age and expertise. Experimental Brain Research, 216(2), 287-297. https://doi.org/10.1007 /s00221-011-2931-5.

Rothman, D. (2016). A tsunami of learners called generation Z. Retrieved from http://www. mdle. net/ JoumaFA_Tsunami_of_Learners_Called_Generation_Z.pdf.

Samaha, M., \& Hawi, N. S. (2016). Relationships among smartphone addiction, stress, academic performance, and satisfaction with life. Computers in Human Behavior, 57, 321-325. https://doi.org/10.1016/j. chb.2015.12.045.

Sarabadani, J., Carter, M., \& Compeau, D. (2018). 10 years of research on technostress creators and inhibitors: Synthesis and critique. In Bush, A. , Grover, V. \& Schiller, S. (Eds.) Proceedings of the twenty-fourth Americas conference on information systems(AMCIS 2018): Vol.1. (pp. 86-95). New Orleans, USA: Association of Information systems

Schlachter, S., Mcdowall, A., Cropley, M., \& Inceoglu, I. (2018). Voluntary work-related technology use during non-work time : A narrative synthesis of empirical research and. International Journal of Management Reviews, 20, 825-846. https://doi.org/10.1111/ijmr.12165.

Shu, Q., Tu, Q., \& Wang, K. (2011). The impact of computer self-efficacy and technology dependence on computer- related technostress: A social cognitive theory perspective. International Journal of HumanComputer Interaction, 27(10), 923-939. https://doi.org/10.1080/10447318.2011.555313.

Srivastava, S. C., Chandra, S., \& Shirish, A. (2015). Technostress creators and job outcomes: Theorising the moderating influence of personality traits. Information Systems Journal, 25(4), 355-401. https://doi. org/10.1111/isj.12067.

Tams, S., Hill, K., \& Thatcher, J. (2013). NeuroIS: Alternative or complement to existing methods ? Illustrating the holistic effects of neuroscience and self-reported data in the context of technostress research. Journal of the Association for Information Systems, 15(10), 723-753. https://doi.org/10.17705 /1jais.00374.

Tarafdar, M., Tu, Q., Ragu-Nathan, B. S., \& Ragu-Nathan, T. (2007). The impact of technostress on role stress and productivity. Journal of Management Information Systems., 24(1), 301-328. https://doi.org/10.2753 /MIS0742-1222240109.

Tarafdar, M., Tu, Q., \& Ragu-Nathan, T. S. (2011a). Impact of technostress on end-user satisfaction and performance. MIS Quarterly, 27(3), 303-334. https://doi.org/10.2753/MIS0742-1222270311. 
Tarafdar, M., Tu, Q., Ragu-Nathan, T. S., \& Ragu-Nathan, B. S. (2011b). Crossing to the dark side: Examining creators, outcomes, and inhibitors of technostress. Communications of the ACM, 54(9), 113-120. https://doi.org/10.1145/1995376.1995403.

Tarafdar, M., Pullins, E. B., \& Ragu-Nathan, T. S. (2014). Technostress: Negative effect on performance and possible mitigations. Information Systems Journal, 25(2), 103-132. https://doi.org/10.1111/isj.12042.

Tarafdar, M., Cooper, C. L., \& Stich, J. F. (2019). The technostress trifecta - techno eustress, techno distress and design: Theoretical directions and an agenda for research. Information Systems Journal, 29(1), 6-42. https://doi.org/10.1111/isj.12169.

Tekinarslan, E. (2008). Computer anxiety: A cross-cultural comparative study of Dutch and Turkish university students. Computers in Human Behavior, 24(4), 1572-1584. https://doi.org/10.1016/j.chb.2007.05.011.

Torkzadeh, G., \& Doll, W. J. (1999). The development of a tool for measuring the perceived impact of information technology on work. The International Journal of Management Science, 27(3), 327-339. https://doi.org/10.1016/S0305-0483(98)00049-8.

Torre, L. G., Esposito, A., Sciarra, I., \& Chiapetta, M. (2019). Definition, symptoms and risk of techno-stress: a systematic review. International Archives of Occupational and Environmental Health, 92(1), 13-35. https://doi.org/10.1007/s00420-018-1352-1.

Vahedi, Z., Zannella, L. \& Want, (2019). Students' use of information and communication technologies in the classroom: Uses, restriction, and integration. Active Learning in Higher Education, 1-14. doi: https://doi. org/10.1177/1469787419861926

Wang, K., Shu, Q., \& Tu, Q. (2008). Technostress under different organizational environments: An empirical investigation. Computers in Human Behavior, 24(6), 3002-3013. https://doi.org/10.1016/j. chb.2008.05.007.

Wang, B., Deng, K., Wei, W., Zhang, S., Zhou, W., \& Yu, S. (2018). Full cycle campus life of college students: A big data case in China. In Du, J. \& Kim, C. (Eds.) Proceedings - 2018 IEEE international conference on big data and smart computing (BigComp). Vol. 1 (pp. 507-512). Washington DC, USA: IEEE Computer Society. doi: 10.1109/BigComp.2018.00083.

Zhao, X., Xia, Q., \& Huang, W. (2020). Impact of technostress on productivity from the theoretical perspective of appraisal and coping processes. Information and Management. https://doi.org/10.1016/j. im.2020.103265.

Publisher's note Springer Nature remains neutral with regard to jurisdictional claims in published maps and institutional affiliations. 